Cereal Research Communications 38(2), pp. 285-293 (2010)

DOI: $10.1556 / C R C .38 .2010 .2 .15$

\title{
Inheritance of $A_{1}$ System of Cytoplasmic-Nuclear Male Sterility in Pearl Millet [Pennisetum glaucum (L). R. Br.]
}

\author{
D. YADAV ${ }^{1,2}$, S.K. GUPTA ${ }^{1}$, V.N. KULKARNI ${ }^{1}$, K.N. RAI $^{1 *}$ and R.K. BEHL ${ }^{2}$ \\ ${ }^{1}$ International Crops Research Institute for the Semi-Arid Tropics (ICRISAT), Patancheru, \\ Andhra Pradesh - 502324, India \\ ${ }^{2}$ Chaudhary Charan Singh Haryana Agricultural University (CCSHAU), Hisar, Haryana-125004, India
}

(Received 29 June 2009; accepted 25 January 2010)

\begin{abstract}
Inheritance of male sterility and fertility restoration of the $A_{1}$ system of cytoplasmic- nuclear male sterility in pearl millet was investigated using 12 crosses among three diverse male sterile lines (A-lines) and four diverse restorers (R-lines). Individual plants from R- lines were used to make crosses on A-lines. The segregation pattern of male sterile $(\mathrm{S})$ and male fertile $(\mathrm{F})$ plants observed in $\mathrm{F}_{2}$ and $\mathrm{BC}_{1}$ in two seasons at ICRISAT, Patancheru was suggestive more likely of a single-gene control of male sterility and fertility restoration. However, a 3-gene model of male sterility/fertility restoration where dominant alleles at any two of the three duplicate complimentary loci will lead to male fertility could not be ruled out, nor could be ruled out a 2-gene control with duplicate interaction. There was indication of variability even within a highly inbred R-line for fertility restoration gene(s). Depending on the genetic constitution of the R-lines at these loci, even the 3-gene model can lead to single-gene segregation ratios as observed in most of the $\mathrm{F}_{2} \mathrm{~S}$ and backcrosses, and 2-gene ratios as observed in a few $\mathrm{F}_{2} \mathrm{~S}$ and backcrosses. The deviations from these expected ratios in some of the crosses influenced by modifiers and environmental conditions generally resulted from the excess of fertile plants in the rainy season or excess of sterile plants in the dry season, the more so in crosses involving an A-line which has been reported to be relatively more unstable for male sterility.
\end{abstract}

Keywords: Pennisetum glaucum, inheritance, $\mathrm{A}_{1}$ cytoplasm, male sterility, fertility restoration

\section{Introduction}

Pearl millet [Pennisetum glaucum (L). R. Br.] is one of the major cereals, grown primarily for grain production on more than 26 million ha in the arid and semi-arid tropical regions of Africa and Asia. India is the largest producer of this crop grown on 10 million ha out of 11 million ha in Asia. Pearl millet cultivation in India is dominated by hybrids that occupy about 4.5 million ha. Pearl millet grain hybrids are also grown to a very limited extent in the United States of America. There is a growing interest in pearl millet grain hybrids in some of the African countries. All the grain hybrids are currently based on the $A_{1}$ system of cytoplasmic-nuclear male sterility (CMS) that was discovered in 1955 at Tifton, Geor-

\footnotetext{
* Corresponding author; E-mail: k.rai@cgiar.org
} 
gia in the USA (Burton 1958). The first grain hybrid HB-1 on $\mathrm{A}_{1}$ CMS system was developed in India in 1965 (Athwal 1965). An understanding of the genetics of male sterility and male-fertility restoration can enhance the efficiency of breeding maintainers (B-lines) and restorers (R-lines). However, even after more than 50 years of extensive utilization, there is little information on the genetics of this CMS system. Based on the fertility restoration behavior of hybrids made on male-sterile lines (A-lines) with the $\mathrm{A}_{1}$ and two additional CMS sources, Burton and Athwal (1967) hypothesized a single recessive gene responsible for male-sterility and its dominant allele for male-fertility restoration. Siebert (1982) suggested two major dominant complimentary genes with at least one modifier to be controlling male fertility restoration in the $A_{1}$ cytoplasm. The objective of this study was to examine the inheritance patterns of male sterility and fertility restoration in a more comprehensive manner, using populations derived by crossing three diverse A-lines based on $\mathrm{A}_{1} \mathrm{CMS}$ system with each of the four diverse R-lines and evaluated in two diverse environments.

\section{Materials and Methods}

The basic experimental material consisted of iso-cytoplasmic A-lines with $\mathrm{A}_{1}$ cytoplasm in three diverse genetic backgrounds and four restorers of diverse parentage. The three $\mathrm{A}_{1}$-lines (81A, ICMA 88004 and 5054A) were developed by more than eight backcrosses of 81B, ICMB 88004 and 5054B, respectively, into 81A with $\mathrm{A}_{1}$ cytoplasm. These three A-lines were crossed with each of the four diverse R-lines (L 67B, IPC 511, IPC 804 and IPC 1518) to produce $12 \mathrm{~F}_{1} \mathrm{~s}$. Individual plants were used for making plant $\times$ plant crosses to produce these $F_{1}$ s. More than 10 plants of each $F_{1}$ were selfed to produce $12 F_{2}$ populations. Bulk pollen from 5-10 plants from each $\mathrm{F}_{1}$ was used to cross on the respective parental A-lines to produce $\mathrm{BC}_{1}$ populations. Each $\mathrm{F}_{1}$ was crossed with bulk pollen from the respective $\mathrm{R}$-line to produce $\mathrm{BC}_{2}$ population.

Field trials of these 7 parents, $12 \mathrm{~F}_{1} \mathrm{~s}, 12 \mathrm{BC}_{1} \mathrm{~s}, 12 \mathrm{BC}_{2} \mathrm{~s}$ and $12 \mathrm{~F}_{2} \mathrm{~s}$ were conducted at the International Crops Research Institute for the Semi-Arid Tropics (ICRISAT), Patancheru, Andhra Pradesh, India, during the summer (March-June) and rainy (July-October) seasons of 2003. The temperature and relative humidity were recorded from the $35^{\text {th }}$ day to the $70^{\text {th }}$ day of crop growth, which refers to one week prior to the flowering of first entry to one week after the last entry came to flowering in each environment. The mean maximum and minimum temperatures during this period in the (dry) summer season were $36^{\circ} \mathrm{C}$ (range $30.4-39.2^{\circ} \mathrm{C}$ ) and $19.9^{\circ} \mathrm{C}$ (range $15.7-23.6^{\circ} \mathrm{C}$ ), respectively. The mean maximum and minimum temperatures during this period in the rainy season were $30^{\circ} \mathrm{C}$ (range 26.4-31. ${ }^{\circ} \mathrm{C}$ ) and $19.6{ }^{\circ} \mathrm{C}$ (range $18-21.4^{\circ} \mathrm{C}$ ), respectively. During the summer season, the mean relative humidity at 0700 hours was $69 \%$ (range $40-95 \%$ ) and at 1400 hours, it was $31 \%$ (range $13-66 \%$ ). During the rainy season, the mean relative humidity at 0700 hours was $88 \%$ (range $80-98 \%$ ) and at 1400 hours, it was $61 \%$ (range $48-76 \%$ ). The parents, $\mathrm{F}_{1}$ 's and $\mathrm{BC}_{2}$ populations were evaluated in single row plots of $4 \mathrm{~m}$ length with approximately $30-35$ plants per plot. Each $\mathrm{F}_{2}$ population was evaluated in eight-row plots of $4 \mathrm{~m}$ length with approximately $250-350$ plants per plot, and each $\mathrm{BC}_{1}$ population was 
evaluated in four rows of $4 \mathrm{~m}$ length with about 125-150 plants per plot. Pollen shedding of individual plants was used to determine male fertility (F) and sterility (S) reaction of individual plants in all the populations. Plants were scored for pollen shedding between 0800 and 1100 hours by tapping the inflorescence and observing for pollen shed. Those shedding pollen were scored as fertile (F) and non-shedders as sterile (S). Chi-square $\left(\chi^{2}\right)$ test was applied on the observed segregation data to test the goodness of fit of various probable genetic ratios.

\section{Results}

All the $12 \mathrm{~F}_{1} \mathrm{~s}$ and the corresponding $12 \mathrm{BC}_{2} \mathrm{~s}$ had all plants fully fertile during both summer and rainy seasons. The $\mathrm{F}_{2}$ population from cross $81 \mathrm{~A} \times \mathrm{L} 67 \mathrm{~B}$ segregated for 272 male-fertile and 51 male-sterile plants during the summer season and fitted well to a ratio of $54 \mathrm{~F}$ : $10 \mathrm{~S}$ with $\chi^{2}$ probability of 1.00 (Table 1 ). Such a segregation ratio would result from a trigenic model where dominant alleles at any two of the three duplicate complimentary loci will lead to fertility restoration. Thus, we hypothesize that the A-line and its maintainer (B-line) both would have the genotype ' $\mathrm{ms}_{1} \mathrm{~ms}_{1} \mathrm{~ms}_{2} \mathrm{~ms}_{2} \mathrm{MS}_{3} \mathrm{MS}_{3}$ '. The genotype of restorer parent would be ' $\mathrm{MS}_{1} \mathrm{MS}_{1} \mathrm{MS}_{2} \mathrm{MS}_{2} \mathrm{~ms}_{3} \mathrm{~ms}_{3}$ '. The $\mathrm{F}_{1}$ would be heterozygous at all the three loci $\left(\mathrm{MS}_{1} \mathrm{~ms}_{1} \mathrm{MS}_{2} \mathrm{~ms}_{2} \mathrm{MS}_{3} \mathrm{~ms}_{3}\right)$, and it would be fertile as found in this study. A plant in the $\mathrm{F}_{2}$ would be fertile if it possesses dominant alleles at least at two of the any three duplicate-complimentary loci (i.e. $\mathrm{MS}_{1} \mathrm{MS}_{2} \mathrm{MS}_{3} / \mathrm{MS}_{1} \mathrm{MS}_{2} \mathrm{~ms}_{3} \mathrm{~ms}_{3} /$ $\left.\mathrm{MS}_{1} \mathrm{~ms}_{2} \mathrm{~ms}_{2} \mathrm{MS}_{3_{-}} / \mathrm{ms}_{1} \mathrm{~ms}_{1} \mathrm{MS}_{2} \mathrm{MS}_{3}\right)$. According to this genetic model, $\mathrm{BC}_{1}$ generation should segregate in $3 \mathrm{~F}: 1 \mathrm{~S}$ ratio. The $\mathrm{BC}_{1}$ of this cross segregated for 114 male-fertile and 42 male-sterile plants during the summer season and fitted well to the expected 3F: $1 \mathrm{~S}$ ratio with $\chi^{2}$ probability of 0.65 . This segregation pattern was repeated during the rainy season with good fit to a $54 \mathrm{~F}: 10 \mathrm{~S}$ ratio in $\mathrm{F}_{2}\left(\chi^{2}=2.42 ; \mathrm{P}=0.12\right)$ and $3 \mathrm{~F}: 1 \mathrm{~S}$ ratio in $\mathrm{BC}_{1}\left(\chi^{2}\right.$ $=3.90 ; \mathrm{P}=0.05)$.

The $\mathrm{F}_{2}$ from the cross, ICMA $88004 \times$ L 67B segregated for 294 male-fertile and 20 male-sterile plants during the summer season and fitted well to a ratio of $15 \mathrm{~F}: 1 \mathrm{~S}$ with $\chi^{2}$ probability of 1.00 . Such a segregation pattern would result from the same hypothesized trigenic model that gives a three-gene ratio, if the A-line had same genotype " $\mathrm{ms}_{1} \mathrm{~ms}_{1} \mathrm{~ms}_{2} \mathrm{~ms}_{2} \mathrm{MS}_{3} \mathrm{MS}_{3}$ " but the restorer parent were dominant homozygote at all the three loci $\left(\mathrm{MS}_{1} \mathrm{MS}_{1} \mathrm{MS}_{2} \mathrm{MS}_{2} \mathrm{MS}_{3} \mathrm{MS}_{3}\right)$, which made the $\mathrm{F}_{1}$ heterozygous only at two loci. The $\mathrm{BC}_{1}$ of this cross segregated for 130 male-fertile and 31 male-sterile plants and gave a good fit to the expected $3 \mathrm{~F}: 1 \mathrm{~S}$ ratio with $\chi^{2}$ probability of 0.11 . This segregation pattern was repeated during the rainy season with a good fit to $15 \mathrm{~F}: 1 \mathrm{~S}$ ratio in $\mathrm{F}_{2}\left(\chi^{2}\right.$ probability of 1.00). The segregation pattern gave a poor fit to the expected $3 \mathrm{~F}: 1 \mathrm{~S}$ ratio in $\mathrm{BC}_{1}$ with $\chi^{2}$ probability of 0.04 due to excess of fertile plants. The $\mathrm{F}_{2}$ from the cross, $5054 \mathrm{~A} \times \mathrm{L} 67 \mathrm{~B}$ also gave a good fit to digenic ratio of $15 \mathrm{~F}: 1 \mathrm{~S}$ in $\mathrm{F}_{2}$ in both the seasons, and to an expected $3 \mathrm{~F}: 1 \mathrm{~S}$ ratio in $\mathrm{BC}_{1}$ in summer season. In the rainy season $\mathrm{BC}_{1}$ ratio did not fit to the expected 3F:1S ratio because of the far too excess of fertile plants. This digenic segregation can also be expected from 2-gene duplication interaction model where A-line would be $\mathrm{ms}_{1} \mathrm{~ms}_{1} \mathrm{~ms}_{2} \mathrm{~ms}_{2}$ and R-line would be $\mathrm{MS}_{1} \mathrm{MS}_{1} \mathrm{MS}_{2} \mathrm{MS}_{2}$. The $\mathrm{F}_{2}$ from cross $81 \mathrm{~A} \times \mathrm{IPC} 511$ 


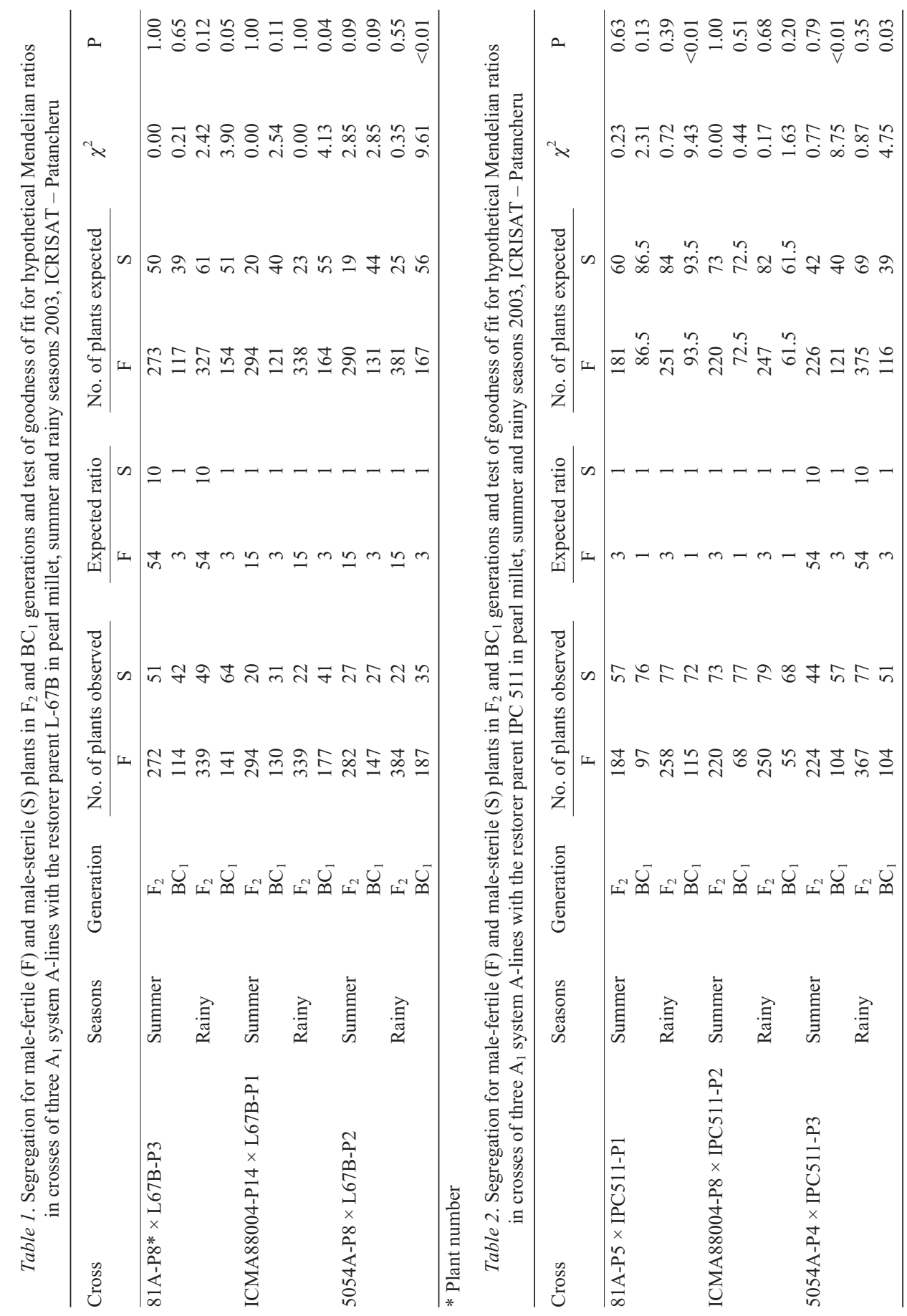

Cereal Research Communications 38, 2010 
segregated for 184 male-fertile and 57 male-sterile plants during the summer season and fitted well to $3 \mathrm{~F}: 1 \mathrm{~S}$ ratio with $\chi^{2}$ probability of 0.63 , and to an expected $1 \mathrm{~F}: 1 \mathrm{~S}$ ratio in the $\mathrm{BC}_{1}$ with a $\chi^{2}$ probability of 0.13 (Table 2 ). Such a segregation pattern could have resulted from the same hypothesized trigenic model suggested above, but in this case, the genotype of the restorer line would be either ' $\mathrm{MS}_{1} \mathrm{MS}_{1} \mathrm{~ms}_{2} \mathrm{~ms}_{2} \mathrm{MS}_{3} \mathrm{MS}_{3}$ ' or ' $\mathrm{ms}_{1} \mathrm{~ms}_{1} \mathrm{MS}_{2} \mathrm{MS}_{2}$ $\mathrm{MS}_{3} \mathrm{MS}_{3}$ ', which would make the $\mathrm{F}_{1}$ heterozygous at only one locus. But such segregation pattern can also result simply from a single-gene control of male sterility and fertility restoration.

In the rainy season also, the $\mathrm{F}_{2}$ of this cross gave a good fit to a $3 \mathrm{~F}: 1 \mathrm{~S}$ ratio, but its corresponding $\mathrm{BC}_{1}$ did not fit to $1 \mathrm{~F}: 1 \mathrm{~S}$ ratio due to excess of fertile plants. In the cross, ICMA $88004 \times$ IPC 511 , the segregation pattern had a good fit to $3 \mathrm{~F}: 1 \mathrm{~S}$ ratio in $\mathrm{F}_{2}$ and $1 \mathrm{~F}: 1 \mathrm{~S}$ ratio in $\mathrm{BC}_{1}$ in both the seasons. In the cross, 5054A $\times$ IPC 511, the segregation pattern gave a good fit to a trigenic ratio of $54 \mathrm{~F}: 10 \mathrm{~S}$ in the $\mathrm{F}_{2}$ in both the seasons.

In the cross, $81 \mathrm{~A} \times \mathrm{IPC} 804$, the segregation pattern had a good fit to $3 \mathrm{~F}: 1 \mathrm{~S}$ ratio in $\mathrm{F}_{2}$ in the rainy season and to $1 \mathrm{~F}: 1 \mathrm{~S}$ ratio in $\mathrm{BC}_{1}$ in both seasons (Table 3 ). The $\mathrm{F}_{2}$ segregation of this cross did not fit to $3 \mathrm{~F}: 1 \mathrm{~S}$ ratio in summer season due to far excess of male-sterile plants. The $\mathrm{F}_{2}$ of the cross, ICMA $88004 \times$ IPC 804 gave good fit to $3 \mathrm{~F}: 1 \mathrm{~S}$ ratio in $\mathrm{F}_{2}$ in both seasons and to $1 \mathrm{~F}: 1 \mathrm{~S}$ ratio in the summer season. The segregation in $\mathrm{BC}_{1}$ in the rainy season did not fit to the expected $1 \mathrm{~F}: 1 \mathrm{~S}$ ratio due to far excess of fertile plants. In cross $5054 \mathrm{~A} \times$ IPC 804, the segregation patterns did not fit the expected ratios of any gene model both in the $\mathrm{F}_{2}$ and $\mathrm{BC}_{1}$ populations in both the seasons.

In cross $81 \mathrm{~A} \times$ IPC 1518 , there were indications of one-gene segregation, but the lack of fit resulted generally from the excess of fertile plants in the rainy season and sterile plants in the summer season, except for the unexpected excess of fertile plants in $\mathrm{BC}_{1}$ in the summer season (Table 4). In cross ICMA $88004 \times$ IPC 1518, segregation patterns gave a good fit to $3 \mathrm{~F}: 1 \mathrm{~S}$ ratio in $\mathrm{F}_{2}$ in the rainy season and to $1 \mathrm{~F}: 1 \mathrm{~S}$ ratio in $\mathrm{BC}_{1}$ in both seasons. The lack of fit to the expected $3 \mathrm{~F}: 1 \mathrm{~S}$ ratio to the $\mathrm{F}_{2}$ in the summer season resulted from far excess of sterile plants. In cross $5054 \mathrm{~A} \times$ IPC 1518, the segregation pattern was not consistent. For instance, while the $\mathrm{F}_{2}$ segregation in the summer season gave a good fit to a $3 \mathrm{~F}: 1 \mathrm{~S}$ ratio in the $\mathrm{F}_{2}$, it did not fit the expected $1 \mathrm{~F}: 1 \mathrm{~S}$ ratio in the $\mathrm{BC}_{1}$. Similarly, while the $\mathrm{F}_{2}$ segregation of this cross gave a good fit to a $54 \mathrm{~F}: 10 \mathrm{~S}$ ratio in the $\mathrm{F}_{2}$ in the rainy season, it did not fit the expected $3 \mathrm{~F}: 1 \mathrm{~S}$ ratio in the $\mathrm{BC}_{1}$.

\section{Discussion}

The overall segregation pattern of male-sterile (S) and male-fertile (F) plants in populations derived from crosses between the two relatively more stable A-lines (81A and ICMA 88004 ) and three diverse R-lines (IPC 511, IPC 804 and IPC 1518) was indicative of a single-gene segregation for male-sterility/fertility restoration, generally giving a good $\chi^{2}$ fit to the expected $3 \mathrm{~F}: 1 \mathrm{~S}$ ratio in $\mathrm{F}_{2}$ and $1 \mathrm{~F}: 1 \mathrm{~S}$ ratio in $\mathrm{BC}_{1}$ populations. Out of 12 cases of $\mathrm{F}_{2} \mathrm{~S}$ from these crosses ( $6 \mathrm{~F}_{2} \mathrm{~S}$ evaluated in two seasons), only three cases that did not have a good fit to an expected 3F:1S ratio were all in the summer season where excess of male-sterile plants were observed. Similarly, out of 12 cases of the $\mathrm{BC}_{1}$ from these 


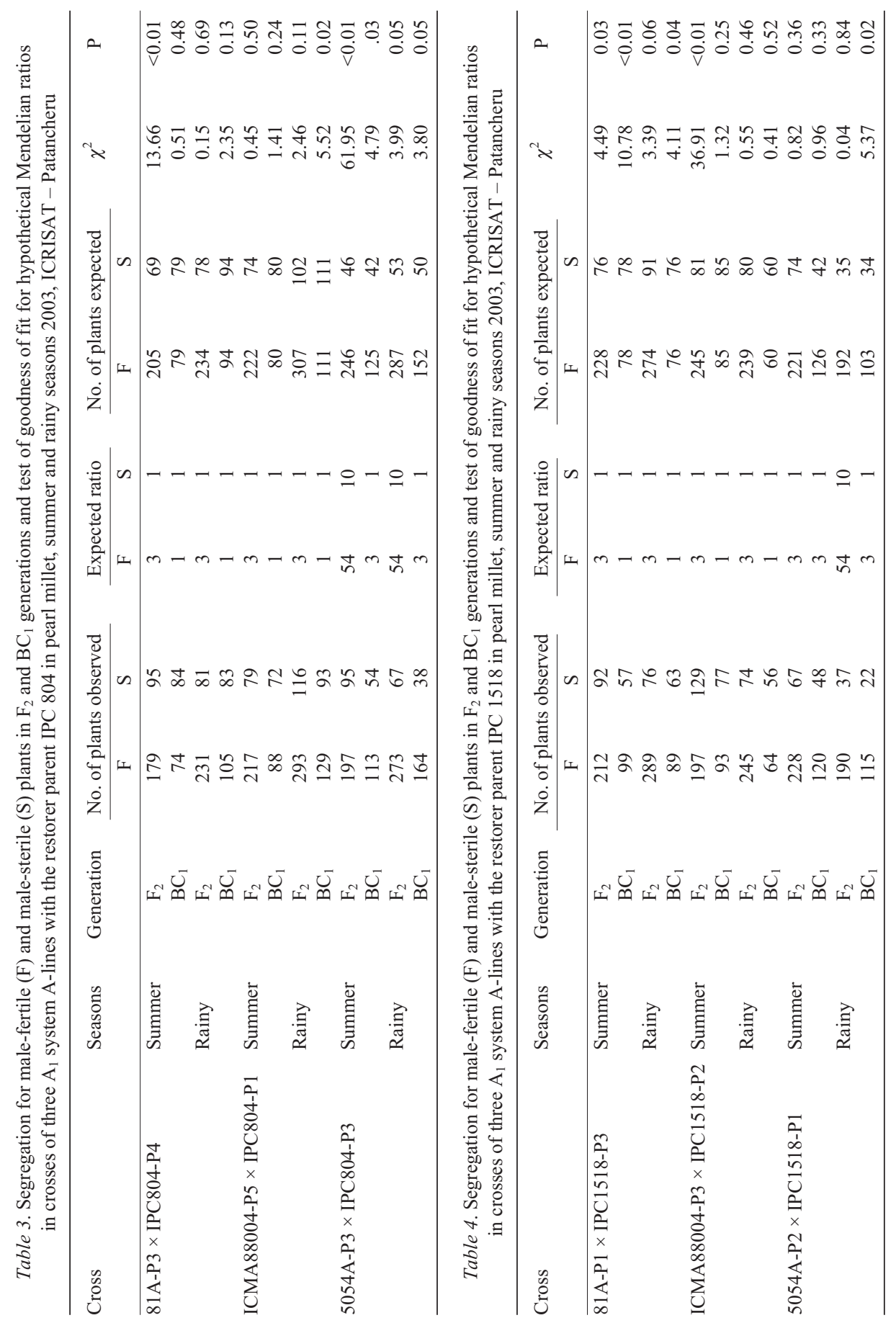

Cereal Research Communications 38, 2010 
crosses, only four cases did not have a good fit to an expected $1 \mathrm{~F}: 1 \mathrm{~S}$ ratio, of which three cases were in the rainy season where excess of fertile plants were observed. Such deviations could likely result from the relatively lower temperatures and higher humidity enhancing the expression of modifiers for fertility restoration in the rainy season, while higher temperatures and lower relative humidity would enhance the expression of modifiers for sterility in the summer season. The effects of these modifiers could be inconsistent, depending on the genetic backgrounds of the segregating populations with the major genes for male sterility/fertility restoration present. Genetical studies in maize (Zea mays) (Singh and Laughnan 1972), sorghum (Sorghum bicolor) (Tripathi et al. 1985), rice (Oryza sativa) (Govinda and Virmani 1988), rapeseed (Brassica napus) (Pahwa et al. 2004), and pepper (Capsicum annum L.) (Wang et al. 2004) have shown considerable effect of the genetic background and environments on the CMS inheritance.

The segregation patterns observed in this study are more likely to arise due to single-gene control system. However, the same segregation pattern arising from a 3-gene control system where R-lines with specific genetic constitution are involved cannot be ruled out, although it appears unlikely because (i) only one out of the three crosses with a specific plant from the same and only one R-line gave 3-gene ratio and (ii) for that to happen the constitution of A-line need to be ' $\mathrm{ms}_{1} \mathrm{~ms}_{1} \mathrm{~ms}_{2} \mathrm{~ms}_{2} \mathrm{MS}_{3} \mathrm{MS}_{3}$ (not very likely to apply to B-lines with diverse pedigree unless the frequency of $\mathrm{MS}_{3}$ gene is very high in the germplasm), and the R-lines should have dominant alleles at the first two loci and recessive allele at the third locus. In fact, 2-gene control system with duplicate interaction may appear to be a more likely situation than the 3-gene control system hypothesized in this study because two $\mathrm{F}_{2}$ populations out of three derived from cross $81 \mathrm{~A} \times \mathrm{L} 67 \mathrm{~B}$ (where different plants of the R-lines were involved in crosses) had a good $\chi^{2}$ fit to the expected $15 \mathrm{~F}: 1 \mathrm{~S}$ ratio in both seasons and $3 \mathrm{~F}: 1 \mathrm{~S}$ expected ratio in $\mathrm{BC}_{1}$ in the summer season. During the rainy season, there was significant deviation from the expected $3 \mathrm{~F}: 1 \mathrm{~S}$ ratio in the rainy season due to excess of fertile plants in this season as also observed in some of the $\mathrm{BC}_{1}$ populations of other crosses. Under the 2-gene control hypothesis with duplicate interaction, the A-line with a genetic constitution of $\mathrm{ms}_{1} \mathrm{~ms}_{1} \mathrm{~ms}_{2} \mathrm{~ms}_{2}$ and the R-line with a genetic constitution of $\mathrm{MS}_{1} \mathrm{MS}_{1} \mathrm{MS}_{2} \mathrm{MS}_{2}$ will give $15 \mathrm{~F}: 1 \mathrm{~S}$ ratio in the $\mathrm{F}_{2}$ and $3 \mathrm{~F}: 1 \mathrm{~S}$ ratio in the $\mathrm{BC}_{1}$ population. Under this hypothesis, $\mathrm{R}$-line being dominant homozygote only at one of the two loci will then give a single-gene inheritance pattern of $3 \mathrm{~F}: 1 \mathrm{~S}$ in the $\mathrm{F}_{2}$ and $1 \mathrm{~F}: 1 \mathrm{~S}$ in the $\mathrm{BC}_{1}$ populations as observed in this study. How often will one encounter 2-gene segregation patterns or 1-gene inheritance patterns will depend on the frequency of dominant restorer alleles at these two loci in pearl millet germplasm. In case, the frequency of restorer allele at one of the two loci is very low to rare, one would find most of the studies producing the results of 1 -gene inheritance under the 2-gene control system. Siebert (1982) reported two major dominant complimentary genes for fertility restoration of $\mathrm{A}_{1}$ cytoplasm in pearl millet.

Highly variable and inconsistent segregation patterns across the crosses and the environments were obtained where 5054A was involved as the female parent. It gave a 2-gene fit to $15 \mathrm{~F}: 1 \mathrm{~S}$ ratio in the $\mathrm{F}_{2}$ in both the seasons and to $\mathrm{BC}_{1}$ ratio of $3 \mathrm{~F}: 1 \mathrm{~S}$ in one season when crossed with $\mathrm{L} 67 \mathrm{~B}$, 3-gene fit to $54 \mathrm{~F}$ : $10 \mathrm{~S}$ ratio in $\mathrm{F}_{2}$ in both seasons, but lack of fit 
to the expected $3 \mathrm{~F}: 1 \mathrm{~S}$ ratio in the $\mathrm{BC}_{1}$ when crossed with IPC 511 , lack of fit to any of these three hypothetical ratios in both populations and both seasons when crossed with IPC 804 , and good fit to $3 \mathrm{~F}: 1 \mathrm{~S}$ ratio in the summer season and to $54 \mathrm{~F}: 10 \mathrm{~S}$ ratio in the rainy season in $\mathrm{F}_{2}$, but lack of fit to the expected ratios in both seasons in $\mathrm{BC}_{1}$ when crossed with IPC 1518. Of the three male-sterile lines used in this study, 5054A has been found to be most unstable for its male sterility as reflected in the relatively higher frequency of pollen shedders observed in this line (Rai et al. 2008). Thus, for a valid interpretation of the genetics of male sterility/fertility restoration, it is important that A-lines with stable male sterility be used in crosses. It is likely that unstable male sterility of 5054A with pollen shedding behavior may lead to excess of fertile plants in both generations, which may convert a $3 \mathrm{~F}: 1 \mathrm{~S}$ ratio in $\mathrm{F}_{2}$ and $1 \mathrm{~F}: 1 \mathrm{~S}$ ratio in $\mathrm{BC}_{1}$ to a $54 \mathrm{~F}: 10 \mathrm{~S}$ ratio in $\mathrm{F}_{2}$ and $3 \mathrm{~F}: 1 \mathrm{~S}$ ratio in $\mathrm{BC}_{1}$. In this respect, it is important to note that $81 \mathrm{~A}$ also throws low frequency of pollen shedders and ICMA 88004 is the most stable A-line. If the 3-gene model of inheritance, although it appears unlikely, is found to hold in future studies, then this study also showed that morphological uniformity of an R-line is not necessarily a reliable indicator of the genetic purity of the line with respect to traits such as fertility restoration in highly cross-pollinated crops like pearl millet. Therefore, even in highly inbred lines, individual plants should be used for making crosses for genetical studies. An earlier study in pearl millet (Hash et al. 2006) showed the existence of significant variability for resistance to downy mildew [Sclerospora graminicola (Sacc.) Schroet.] even in highly inbred lines of pearl millet.

\section{Acknowledgements}

Part of a Ph.D. thesis of D. Yadav submitted to CCSHAU (Chaudhary Charan Singh Haryana Agricultural University), Hisar, Haryana, with the research work carried out at the International Crops Research Institute for the Semi-Arid Tropics (ICRISAT), Patancheru, Andhra Pradesh, India. The senior author would like to acknowledge and thank the grant of scholarship by CCS HAU, Hisar and ICRISAT during the doctoral study and the former and present staff of ICRISAT's pearl millet breeding team for help in field work during the study. Partial funding support for this work from the Pearl Millet Hybrid Parents Research Consortium is gratefully acknowledged.

\section{References}

Athwal, D.S. 1965. Hybrid bajra-1 marks a new era. Indian Farming 15:6-7.

Burton, G.W. 1958. Cytoplasmic male sterility in pearl millet (Pennisetum glaucum (L.) R. Br). Agron J. 50: 230-231.

Burton, G.W., Athwal, D.S. 1967. Two additional sources of cytoplasmic male sterility in pearl millet and their relationship to Tift 23A. Crop Sci. 7:209-211.

Govinda, R., Virmani, S.S. 1988. Genetics of fertility restoration of 'WA' type cytoplasmic male sterility in rice. Crop Sci. 28:787-792.

Hash, C.T., Thakur, R.P., Rao, V.P., Bhaskar Raj, G. 2006. Evidence for enhanced resistance to diverse isolates of pearl millet downy mildew through gene pyramiding. Int. Sorghum and Millets Newsl. 47:134-138.

Pahwa, R.S., Banga, S.K., Gogna, K.P.S., Banga, S.S. 2004.Tournefortii male sterile system in Brassica napus. Identification, expression and genetic characterization of male sterile restorers. Plant Breed. 123:444-448. 
Rai, K.N., Khairwal, I.S., Dangaria, C.J., Singh, A.K., Rao, A.S. 2008. Seed parent breeding efficiency of three diverse cytoplasmic-nuclear male sterility systems in pearl millet. Euphytica 165:495-507.

Siebert, J.D. 1982. Genetic and breeding aspects of fertility restoration in cytoplasmic male sterile pearl millet. Ph.D. Thesis, University of Georgia, Athens, Georgia, USA. 151 pp.

Singh, A., Laughnan, J.R. 1972. Instability of S male sterile cytoplasm in maize. Genetics 71:607-620.

Tripathi, D.P., Rana, B.S., Rao, N.G.P. 1985. Genetics of fertility restoration in sorghum. Indian J. Genet. 45: 292-301.

Wang, L.H., Zhang, B.X., Lefebvre, V., Huang, S.W., Daubeze, A.M., Palloix, A. 2004. QTL analysis of fertility restoration in cytoplasmic male sterile pepper. Theor. Appl. Genet. 109:1058-1063. 